\title{
КРАТКИЙ ОЧЕРК О СУДЬБЕ РОССИЙСКОГО КОНСТИТУЦИОНАЛИЗМА: О СУЩНОСТИ, ЭВОЛЮЦИИ И НЕОТЛОЖНОСТИ КОНСТИТУЦИОННОЙ РЕФОРМЫ
}

\begin{abstract}
Аннотация: Предметом исследования в данной статье стали российский конституционализм, его сущность, принципы и факторы, позволяющие ему реализоваться, а также перспективы конституционного целеполагания в России в свете неизбежности конституционного реформирования. Внимательнейшим образом рассматривается понятие конститучионализма, подвергается анализу история его развития в рамках российского государства. На основе собственных исследований, а также изучения многочисленных работ ученых и сравнения декларируемых Конституцией положений с политико-экономическими и социально-культурными реалиями автор делает справедливый вывод о глубоких противоречиях российского конституционализма, позволяющих говорить о его несостоятельности. В ходе исследования использовались методы классификации, анализа и синтеза, сравнительно-правовой, эмпирический и исторический. Статья обладает элементами научной новизны, заключающимися в формулировании авторского понятия кон-ституционализма, его ключевых признаков и основных условий существования российского конституционализма, а также в определении вектора конституционного иелеполагания в России и основных предпосылок конституционной реформы.

Abstract: The object of study in this article is Russian constitutionalism, its nature, principles and factors, allowing for its implementation, as well as the perspectives of constitutional target-setting in Russia in the light of urgent need for constitutional reform. The author pays much attention to the definition of constitutionalism, as well as the history of its development in the Russian state. Based upon his own study and analysis of numerous works of legal scholars, as well as upon the comparison of provisions declared by the Constitution with the political, economic, social and cultural reality, then the author draws a conclusion that there are deeply rooted contradictions in the Russian constitutionalism, and they allow one to call it non-sustainable. In the process of studies the author used the following methods: classification, analysis, synthesis, comparative legal studies, empirical and historic methods. The article includes scientifically novel elements, such as author's definition of constitutionalism, as well as defining the vector for the constitutional target-setting in Russia and the main prerequisites for the constitutional reform.
\end{abstract}

Ключевые слова: государственная система, конституиионализм, конституционная реформа, конституционный кризис, конституциия, правовая культура, социальные системы, управление, функиии конституции, целеполагание Keywords: state system, constitutionalism, constitutional reform, constitutional crisis, constitution, legal culture, social systems, administration, functions of the constitution, target-setting.

\section{Преамбула}

вадцатилетие Конституции Российской Федерации подвигло ученых-конституционалистов, да и практиков к переосмыслению периода действия Основного закона страны, всеобъемлющему и всестороннему анализу взаимосвязи и взаимообусловленности основополагающих норм и принципов Конституции с реалиями общественно-политической жизни. Но сказать, что эта весьма актуальная тема была на «задворках» научных исследований и дискуссий все прошедшие годы, было бы крайне неучтиво по отношению к научному сообществу и всем, кого в той или иной мере тревожит судьба России. Велись исследования, шла активная научная дискуссия ${ }^{1}$.

\footnotetext{
${ }^{1}$ Среди наиболее известных публикаций по тематике конституционализма можно выделить следующие: Степанов И.М. Уроки и парадоксы российского конституционализма. - М., 1996; Он же. Грани российского конституционализма (XX век) // Конституционный строй России. - М., 1992; Кравец И.А. Формирование российского конституционализма: проблемы теории и практики. Новосибирск, 2002; Он же. Конституционализм: устойчивость власти и общественного развития. - Новосибирск: Изд-е ИФиПр СО РАН, 1994; Он же. Конституционализм и российская государственность в начале XX века: Учеб. пособие. - М.: ИВЦ «Маркетинг»; Новосибирск: ООО «Издательство ЮКЭА», 2000; Авакьян С.А. Конституция России: природа, эволюция, современность. - М.: РЮИД, 1997; Авакьян С.А. Точка отсчета - народ // Российская
} 
DOI: $10.7256 / 1811-9018.2013 .12 .10142$

При цитировании этой статьи сноска на доі обязательна

\section{Право и политика $12(167) \cdot 2013$}

«Идеи конституционного реформирования, сами по себе высказывавшиеся не так уж редко в нашем обществе, в последнее время стали связываться с несистемной оппозицией. А поскольку ее “авангардная” часть ведет себя неадекватно, власть удачно использует промахи, в том числе по части идей. В этой ситуации, даже если есть объективные причины для демократизации и реформирования российского общества и конституционного строя, они постепенно задвигаются на очень задний план.

Между тем вопрос о необходимости конституционного реформирования, о том, как его проводить, существует объективно. И, думается, пришло время от истошных выпадов против конкретных личностей и партий перейти к обстоятельной дискуссии»².

\section{О сущности конституционализма}

Конституционализм определяется в конституционно-правовой науке как комплексная общественнополитическая и государственно-правовая категория, основы которой составляют идеалы конституционной демократии, наличие определенных институтов власти, соответствующего конституции политического режима и системы защиты ценностей демократии, прав и свобод человека и гражданина, конституционного строя в целом³

Конституционализм в литературе часто упоминается также как политическая система, опираю-

газета. - 2006. - 28 окт.; Он же. Конституция Российской Федерации: норма и действительность // Неприкосновенный запас. - 2008. - № 5 (61); Он же. Десять причин для конституционных реформ в России // Независимая газета. - 2012. - 16 окт.; Лучин В.О. Конституция Российской Федерации: Проблемы реализации. - М.: ЮНИТИ-ДАНА, 2002; Боброва Н.А. Конституционный строй и конституционализм в России. - М.: ЮНИТИ-ДАНА, Закон и право, 2003 ; Чиркин B.E. Конституционализм и современная цивилизация // Труды Института государства и права РАН. - 2006. - № 3 (Конституционный строй России. Вып. 5). - М., 2006; Богданова Н.А. Категория «конституционализм» в науке конституционного права // Российский конституционализм: проблемы и решения. - М., 1999; Топорнин Б.Н. Конституционная реформа - путь к правовому государству// Советское государство и право. - 1990. - № 4; Государственный строй монархической России: реалии, проекты, идеи, споры / Под. ред. Ю.Л. Шульженко. - М., 2008; Егоров С.А. Конституционализм в США: политико-правовые аспекты. - М., 1993; Глигич-Золотарева М.В. Фрагментарный конституционализм // Труды Института государства и права РАН. - 2006. - № 3 (Конституционный строй России. Вып. 5). - М., 2006 и др.

2 Авакьян С.А. Десять причин для конституционных реформ в России // Независимая газета. - 2012. - 16 окт.

${ }^{3}$ Конституционное право: Энцикл. словарь / Под ред. С.А. Авакьяна. - М., 2000. - С. 304-305. щзаяся на конституичию, конституичионные методы правления 4 .

Конституционализм по Н.А. Богдановой - cuстема основных идей и взглядов об отвечающем принципам демократического развития устройстве государства, организации в нем власти и взаимоотношениях последней с гражданами 5 .

По мнению И.А. Кравца, наличие самой конституции предопределяет реальное существование конституционализма во многом, но не во всем. «Хотя конституционализм основывается на конституции, $c a-$ мой конституции как правового акта, по всей вероятности, еще недостаточно, чтобы конституционализм стал фактом действительности» ${ }^{6}$. С ним согласно большинство авторов, занимающихся проблемами конституционализма.

Принятие юридической конституции, по словам Б.Н. Топорнина, «не свидетельствует о становлении или функционировании правового государства»7. Перефразируя автора, полагаем уместным сделать вывод: конституцуионализм может сущеествовать и без конституции, но конституцฺия без конституцฺионализма лишена всякого смысла ${ }^{8}$.

Как считает С.А. Егоров, почти каждое государство имеет конституцию в смысле институциональной структуры и установленных процедур для ведения политических дел, но отнюдь не каждое государство является конституционным государством. «Конституционное правление существует там, где определеннье нормы и процедуры ограничивают осуществление власти». В стране может наличествовать конституция, но может не быть конституционализма, поскольку последний это «совокупность таких соииально-экономических, политических, правовых, психологических, этических, культурно-исторических и иных условий, при которых конституция функционирует как достаточно эффективный ограничитель государственной власти». Там, где конституционализм является определяющей чертой политического режима, конституция первична: она как

\footnotetext{
${ }^{4}$ Словарь иностранных слов. - М., 1984. - С. 247.

${ }^{5}$ Богданова Н.А. Система науки конституционного права. - М.: Юристъ, 2001. - С. 164.

${ }^{6}$ Кравец И.А. Конституционализм: устойчивость власти и общественного развития. - Новосибирск: Изд-е ИФиПр СО РАН, 1994. - C. 9-10.

${ }^{7}$ Топорнин Б.Н. Конституционная реформа - путь к правовому государству // Советское государство и право. -1990 . - № 4. - С. 5.

${ }^{8}$ По словам Б.Н. Топорнина, «правовая система может существовать без конституции, а конституция без правовой системы - немыслимое явление». См.: Топорнин Б.Н. Указ. соч. - С. 4.
} 
DOI: $10.7256 / 1811-9018.2013 .12 .10142$

При цитировании этой статьи сноска на dоі обязательна

Правовая и политическая мысль

бы «предшествует» государственной власти, а лица, которые находятся у власти, связаны ее положениями как нормами верховного права'.

Отсюда напрашивается следующий вывод: для конституционализма крайне важно, чтобы конституция как основной правовой акт государства поддерживалась всем строем общественной и государственной жизни.

Чтобы определить меру такой поддержки, ее более четкие параметры, обратимся к принципам конституционализма.

И.А. Кравцом выделено шесть наиболее значимых принципов конституцуионализма, среди которых:

первый: верховенство и господство права;

второй: ограничение государственной власти;

третий: институциональный контроль над правителями;

четвертый: суверенитет народа, связь государственной власти с народом;

пятый: разделение властей;

шестой: легитимность государственной власти.

Необходимость действенности конституции определяет такой принцип конституционализма, как верховенство права. Формирование и деятельность политических институтов при конституционной политической системе происходят в правовых рамках, а каждый орган или институт государства имеют правовое оформление. То есть:

во-первых, «вершиной верховенства права являются теория и практика конституционализма, в которых конституции отводится роль Основного закона в государстве, а вся остальная правотворческая деятельность должна иметь конституционные предель»;

во-вторых, «конституционализм как высшее выражение верховенства права должен служить ограждению соичильных институтов от деформационных сдвигов, связанных с ее захватом и узурпациией»;

8-третьих, «правление в государстве должно быть ограничено не только самим фактом существования конституции, но и таким положением вещей, при котором предотвращена возможность сосредоточения власти в одних руках или в одном органе до такой степени, что она становится угрозой для свободы личности» ${ }^{10}$.

Таким образом, конституционализм - это не только и не столько нормативная система и правовая реальность. Конституционализм должен опираться на определенные ценности как неотъемлемую часть

\footnotetext{
${ }^{9}$ Егоров С.А. Конституционализм в США: политико-правовые аспекты. - М.: Наука, 1993. - С. 9-10.

${ }^{10}$ Подробнее об этом см.: Кравеи И.А. Указ. соч. - С. 9-11.
}

правосознания личности и правовой культуры в целом. «Системный анализ современного российского конституционализма охватывает четыре грани его воплощения в реальности: идейно-теоретический, нормативно-правовой, институцчионально-функциональный и судебно-интерпретационныци» ${ }^{11}$.

Как мы уже установили, решающее для конституционализма значение имеют не столько писаные нормы Основного закона, сколько практика их реализации и тот культурно-идеологический бэкграунд, на фоне которого конституционализм зреет и эволюционирует.

Как справедливо замечает Ю.А. Шульженко, «в наши дни конституционализм трактуется как сложная, многоплановая, общественно-политическая, государственно-правовая категория. Наиболее целесообразно и продуктивно рассматривать конституционализм с двух сторон. Во-первых, как реальную государственноправовую практику. Ее атрибутом является наличие конституции как особого документа общества, государства, занимающего верховное положение в отношении всех элементов политической системы, их актов, обладающего высшей юридической силой в правовой иерархии. Во-вторых, конституционализм теоретический, который представляет собой сумму знаний по данной проблематике в обществе. Он находит свое выражение главным образом в конституционных проектах, документах политических партий, высказываниях представителей политической мысли и, особенно, в трудах ученых-государствоведов» ${ }^{12}$.

Конституционализм как реальный общественный феномен характеризуется особенностями функционирования публичной власти. До Монтескье, полагает А. Янов, политическая система всегда строилась по вертикальному принципу, представляя собой более или менее совершенную иерархию, «подобно готическому собору венчавшуюся шпилем - единоличным лидером» ${ }^{13}$. Монтескье был одним из первых авторов, предложивших новый принцип построения политической системы - принцип политической горизонтали, в основе которого лежат «три равноправных, уравновеииваюших друг друга института власти». По мнению И.А. Кравца, «такая система сложна и первоначально малоэффективна, она может служить устойчивому раз-

\footnotetext{
${ }^{11}$ Кравеи И.А. Формирование российского конституционализма (проблемы теории и практики). - М.-Новосибирск: ООО «Издательство ЮКЭА», 2002. - С. 6, 155.

${ }^{12}$ Государственный строй монархической России: реалии, проекты, идеи, споры / Под. ред. Ю.Л. Шульженко. - М., 2008. - С. 6.

${ }^{13}$ Янов А. Монтескье против Маркса // Общественные науки и современность. - 1992. - № 1. - С. 88.
} 
DOI: $10.7256 / 1811-9018.2013 .12 .10142$

При цитировании этой статьи сноска на dоі обязательна

\section{Право и политика $12(167) \cdot 2013$}

витию общества после того, как пустит корни в политическую культуру и обыденное сознание населения»»

Показательно, что данная модель полностью согласуется с системными представлениями об устройстве государства как сложной социальной системы.

Как пишет М.В. Глигич-Золотарева, «иерархическая структуризация более эффективна в качестве краткосрочной тактики, но контрпродуктивна в качестве долговременной стратегии, она требует незначительного ресурсного обеспечения на начальном этапе - но в дальнейшем довольно ресурсоемка, потенциал ее развития незначителен. Сетевая структуризация на ранних этапах не дает особенных результатов и требует значительных ресурсов - однако в перспективе функционирование сетевых систем довольно стабильно и не требует значительных затрат вследствие механизмов самоорганизации и способности элементов системы получать ресурсы извне» ${ }^{15}$. Иными словами, государственную систему, основанную на принципах конституиионализма, сложнее создать, нежели традиционную иерархическую систему, однако она гораздо продуктивнее в долгосрочной перспективе.

Немыслим конституционализм и без соблюдения принципа участия. «Конституционализм не может быть осуществлен... без всеобщего согласия различных социальных групп... с имеющейся в данном обществе формой правления... Именно консенсус является той необходимой опорой, без которой конституционализм провисает в воздухе или остается на бумаге» ${ }^{16}$. Или, как пишет А.Е.Дик Ховард, одним из признаков конституционализма является утверждение, что правительство происходит из народа и существует в согласии с ним ${ }^{17}$.

Как полагает И.М. Степанов, конституционализм можно рассматривать в узком и широком смысле. $B$ широком смысле это явление охватывает теорию конституичи, историю и практику развития страны. В узком смысле под конституционализмом понимается система знания о фундаментальных иенностях демократии: их составе, формах выражения, методах и степени реализации, система представлений об общедемократических, общецивилизационных по-

\footnotetext{
${ }^{14}$ Кравеи И.А. Конституционализм: устойчивость власти и общественного развития. - Новосибирск: Изд-е ИФиПр СО РАН, 1994. - C. 17.

${ }^{15}$ Глигич-Золотарева М.В. Теория и практика федерализма: системный подход. - Новосибирск: Наука, 2009. - С. 506-507.

${ }^{16}$ Кравец И.А. Указ. соч. - С. 18.

${ }^{17}$ Цит. по: Верховенство права: Сб. / Пер. с англ. - М.: Прогресс, 1992. - C. 53.
}

литико-правовых ценностях государственно организованного общества ${ }^{18}$.

С ним в целом согласен С.А. Авакьян, однако с той оговоркой, что «указанные общие ценности следует трактовать как набор нужных, желательных в любой стране. Однако нельзя их рассматривать как некую аксиоматическую заданность (курсив автора. - Н.Д.) и соизмерять с нею то, что имеет место в конкретном государстве. В этом случае анализ реальности, в том числе и достижений соответствующего общества, невольно подменяется формальными критериями: есть все из набора - значит, государство может похвалиться наличием конституционализма, чего-то недостает значит, до “подлинного" конституционализма еще путь не пройден» $»^{19}$. Кроме того, как справедливо замечает автор, само понятие «общедемократических» и «общеиивилизационных» иенностей весьма относительно, поскольку многие традиционно демократические страны не обладают рядом необходимых «демократических» атрибутов: так, например, в той же Великобритании отсутствует писаная конституция, что не мешает ей в течение нескольких столетий оставаться образцовым демократическим государством.

Мы полностью согласны с мнением С.А. Авакьяна. Тем более что в последнее время многие ключевые понятия конституционного права, такие как «демократия», «права человека», «правовое государство» и прочие, подверглись столь сильной смыссловой диффузии и даже дискредитаиии, что крайне сложно теперь установить их истинный смысл.

В начале 20-х годов прошлого века аналогичную ситуацию, сложившуюся в публично-правовой сфеpe, описал отечественный правовед М.А. Рейснер: «Конституции во время войны за полной своей ненадобностью настолько основательно были сданы на хранение, что и теперь по ее окончании никак не могут прийти в силу. Военное положение заменило их с большим успехом и после войнь. Закон уступил место приказам и распоряжениям бесчисленных диктаторов, установленных законом же, так что закон отменил самого себя. Из пресловутого разделения властей вылупилась одна всемогущая исполнительная власть, которая поработила все прочие... Инельзя в достаточноймере оценить тот моральный и юридический пере-

\footnotetext{
${ }^{18}$ Степанов И.М. Уроки и парадоксы российского конституционализма. - М., 1996. - С. 3; Он же. Грани российского конституционализма (XX век) // Конституционный строй России. Вып. 1. - М., 1992. - C. 30-31.

${ }^{19}$ Авакьян С.А. Конституция России: природа, эволюция, современность. - М.: РЮИД, 1997. - С. 223.
} 
DOI: $10.7256 / 1811-9018.2013 .12 .10142$

При цитировании этой статьи сноска на dоі обязательна

Правовая и политическая мысль

ворот, который произошел благодаря такому полному разрушению старых фикций и верований. Все, что было освящено длительной привычкой и твердым обычаем, во что верили как в нерушимую норму и правило, все это полетело вверх ногами, все оказалось вздорной выдумкой и ненужным стеснением» ${ }^{20}$.

Перед нами одно из наиболее полных описаний деконституциионализации - этого антипода конституичионализма.

К сожалению, современная ситуация в конституционно-правовой сфере характеризуется некоторыми из указанных принципов, что не является поводом для юридического оптимизма. Мы не можем не согласиться с М.В. Глигич-Золотаревой, которая пишет: «Сегодня, как, впрочем, и в начале $\mathrm{XX}$ века, наблюдается сходная по своим признакам и последствиям эрозия основных дефиниций публичного права... системный кризис традиционных государственных институций, в корне которого лежит несоответствие “трех китов” современного общества и государства - демократии, парламентаризма и разделения властей - реалиям интенсивно меняющзегося мира» ${ }^{21}$.

По мнению С.А. Авакьяна, конституционализм существует в четырех основных ипостасях:

первая: конституциионные идеи;

вторая: наличие соответствующего нормативноправового фундамента;

третья: достижение определенного фактического режима;

четвертая: система защиты конституциионного строя и конституции.

В качестве предпосылок конституцчионализма, по мнению автора, следует рассматривать:

во-первых, глубокое почитание связанности государства и общества правом, законом;

во-вторых, внедрение в общественное сознание $и$ бытие идеи приоритета человеческой личности;

в-третьих, участие непосредственно народа в осуществлении функций власти, не просто наличие определенных государственных органов, но демократический порядок их формирования, всеобщая подчиненность интересам народа деятельности этих органов;

в-четвертых, наличие прочессуальных механизмов защчиты прав и свобод граждан;

${ }^{20}$ Рейснер М.А. Государство буржуазии и РСФСР. - М.-Пг: Госиздат, 1923. - С. 221, 222.

${ }^{21}$ Глигич-Золотарева М.В. Верификация дефиниций конституционной науки vs. увлечение общими местами // Политика и общество. -2009 . - № 5. в-пятых, общественное сознание, построенное на убежденности в необходимости и пользе институтов власти и государственных законов, их оформляющчих, возможности достижения сочииальной справедливости ${ }^{22}$.

Нами, на основе исследования обширного массива работ ученых-конституционалистов, делается вывод, что традиционно конституционализм включает в себя следующие ключевые положения.

Первый. Комплекс конституциионных идей, среди которых идея власти права, закона, приоритет человеческой личности, народовластие, демократический порядок формирования органов государственной власти, их подчиненность интересам народа, наличие механизмов защиты прав и свобод человека, ориентированность на социальную справедливость.

Второй. Нормативно-правовой фундамент, проявляющийся, прежде всего, но не только, в принятии конституции, закрепляющей перечисленные институты; при этом конституция может быть и неписаной либо ее содержание может поглощаться особого рода законами, играющими роль основного закона.

третий. Политический режим, адекватный конституции, гарантией которого является развитая система защиты конституционного строя и конституции; авторитет конституции в общественном сознании должен быть высок и непререкаем.

\section{Об эволюции российского конституционализма}

Анализ указанных признаков на примере отечественных реалий чаще всего приводит исследователей, в числе которых и мы, к выводу о том, что конституичионализм в полном смысле этого слова в России пока еще не сложился.

По мнению В.Е. Чиркина, Конституция России «закрепила переход от тоталитаризма к демократии, сыграла огромную роль в развитии нового российского общества, в становлении новой государственности и формировании личности, свободной от тоталитарных оков. Ее демократический потенциал далеко не исчерпан» ${ }^{23}$.

Да, нельзя не признавать, что обширный комплекс конституционных идей развивается. В то же время с третьим признаком конституционализма, а именно - с наличием политического режима, адекватного конституции, гарантией которого является развитая

\footnotetext{
${ }^{22}$ Авакьян С.А. Указ. соч. - С. 224-226.

${ }^{23}$ Чиркин B.E. Реформа российской Конституции: этапы и проблемы // Общественные науки и современность. 2000. - № 5. - C. $42-61$.
} 
DOI: $10.7256 / 1811-9018.2013 .12 .10142$

При цитировании этой статьи сноска на dоі обязательна

\section{Право и политика $12(167) \cdot 2013$}

система защчиты конституцฺионного строя, - страна испытывает серьезные трудности.

Отсутствие сложившейся непрерывной традиции отечественного конституционализма, его дискретность и фрагментарность подмечены многими конституционалистами. Н.А. Боброва пишет о незавершенности перехода России к конституичинному государству. Современный российский конституционализм, по ее мнению, можно охарактеризовать как либеральный по содержанию и бюрократический по форме ${ }^{24}$.

Посвященная рассматриваемой проблематике работа М.В. Глигич-Золотаревой называется «Фрагментарный конституционализм» ${ }^{25}$. По мнению автора, «Основной закон страны мало соответствует реальным общественным отношениям, система защиты конституционного строя не срабатывает, положения Конституции на каждом шагу подменяются законодательными либо подзаконными актами, а подчас - и вовсе практикой их применения, вследствие чего авторитет Конституции в общественном сознании крайне низок».

А.Н. Медушевский излагает свою позицию о мнимом конституционализме, который «становится возможным в тех странах, где демократические силы не имеют реальной социальной опоры, распылены и вынуждены в силу этого апеллировать к государству; власть отделена от общества, а монарх становится в полной мере заложником бюрократии, не находя ей противовеса в народном представительстве» ${ }^{26}$.

И.А. Кравцом выделены ключевые элементы монархического конституционализма начала XX века в России, среди которых двухпалатный парламент (в лице Государственной Думы и Государственного Совета) и Совет Министров, практически независимый от парламента ${ }^{27}$. Российская модель конституционализма, в отличие от европейской, традиционно отрицала всякую ответственность министров перед законодательными органами. В современной России также существуют двухпалатный парламент (в лице Государственной

\footnotetext{
${ }^{24}$ Боброва Н.А. Конституционный строй и конституционализм в России. - М.: ЮНИТИ-ДАНА, Закон и право, 2003. - С. 8, 25.

${ }^{25}$ Глигич-Золотарева М.В. Фрагментарный конституционализм // Труды Института государства и права РАН. - 2006. - № 3 (Конституционный строй России. Вып. 5). - 2006. - № 3. - М., 2006.

${ }^{26}$ Медушевский А.Н. Конституционная монархия в Европе, Японии и России // Общественные науки и современность. - 1994. - № 6. - С. 74; Он же. Что такое мнимый конституционализм? // Социологические исследования. - 1994. - № 2.

${ }^{27}$ Кравец И.А. Конституционализм и российская государственность в начале XX века: Учеб. пособие. - М.: ИВЦ «Маркетинг»; Новосибирск: ООО «Издательство ЮКЭА», 2000. - С. 317-328.
}

Думы и Совета Федерации) и Правительство, практически не ответственное перед Федеральным Собранием. Как продолжает И.А. Кравец, «в новой Конституции России принцип ответственности правительства перед парламентом носит во многом условный характер и поставлен в зависимость от усмотрения президента» ${ }^{28}$.

Конституционализм в России носит ярко выраженный октроированныци характер, даже несмотря на то, что новейшая российская история знала и другие его формы. В 90-х годах прошлого века имели место всенародное голосование по проекту Конституции в 1993 г. (существенный признак народного конституционализма) и подписание Федеративного договора (элемент договорного конституционализма). Однако Конституцию 1993 г. не зря назвали «ельцинской»: она была разработана благодаря усилиям главы государства, полностью отвечала его интересам и вступила в силу благодаря слому прежней конституционной системы, легитимность которого до сих пор вызывает многочисленные споры; более того, в тот период высказывались мнения об антиконституциональном перевороте. И если по формальным признакам российский конституционализм можно рассматривать как народныли, то по сути это - дарованнылй сверху, октроированный конституц̧ионализм.

Современный российский конституционализм носит и так называемый дуалистический характер. И.А. Кравец описывает конституционные реалии России начала XX века следующим образом: «Государственный режим сохраняет черты дуалистической системы, хотя конституционная регламентация права Государственной Думы выражать недоверие правительству означает возникновение первых элементов парламентаризма». Эти реалии практически ничем не отличаются от современных: «Доминирование главы государства, который не включен в структуру исполнительной власти, но наделен широким перечнем характерных для нее полномочий, свидетельствует о преемственности неизжитой традиции сильной монархической власти в истории России». Дуалистическая монархия, по мнению И.А. Кравца, - это промежуточная форма правления между абсолютной и парламентарной монархией. Монарх назначает главу правительства и министров, отвечающих перед ним, а не перед парламентом. Парламент наделен законодательной властью, монарх сохраняет право на его роспуск и пользуется правом абсолютного вето.

«В России в период преобразований возник пере-

\footnotetext{
${ }^{28}$ Там же. - С. 345.
} 
DOI: $10.7256 / 1811-9018.2013 .12 .10142$

При цитировании этой статьи сноска на dоі обязательна

Правовая и политическая мысль

ходный от абсолютизма к конституционализму тип государственности, который... может быть охарактеризован как сегментарный. В такой форме государства сосуществуют конституционные и традиционные институты власти, между которыми разделены функции и роли по управлению обществом. При этом нормами права и конституцией закреплен значительный перевес за исполнительной властью и главой государства» ${ }^{29}$. Эту мысль развивает В.В. Леонтович: «Неразвитость гражданского строя, гражданской свободы и повела к исчезновению политической свободы, к крушению конституционного строя в России» $)^{30}$.

Очевидно, что вековые (как минимум - с начала XX века, а то и с момента появления первых конституционных проектов, восстания декабристов и известного тезиса про «Константина и жену его Конституциюю (то есть с начала XIX в.)) проблемы конституционализма в России не могли возникнуть на «пустом месте».

Одной из основных причин фрагментарности отечественного конституционализма, по мнению В.О. Лучина, является конституциионный кризис, то есть «системный кризис всех основных сфер общественной жизни, проявляющийся в девальвации Конституции, резком расхождении ее с общественной практикой; функционировании социально-экономических, политических, государственно-правовых институтов с существенным отступлением от требований Конституции; разрушении единого конституционно-правового пространства, длительном бездействии или ненадлежащем действии конституционных и иных правовых норм, массовом безнаказанном их нарушении, достигающем критических величин... Конституционная и общественная практика в современной России как бы разведены по разным орбитам и пересекаются лишь в удобных и выгодных для правящего режима координатах. И чем больше конституционный люфт, тем сильнее и глубже конституционный кризис» ${ }^{31}$.

Основные причины конституционного кризиса группируются вокруг главного - бросающегося в глаза резкого расхождения положений Конституции с

\footnotetext{
${ }^{29}$ Кравеи И.А. Конституционализм и российская государственность в начале XX века: Учеб. пособие. - М.: ИВЦ «Маркетинг»; Новосибирск: ООО «Издательство ЮКЭА», 2000. - С. 314, 339, 345-346.

${ }^{30}$ Леонтович В.В. История либерализма в России. 1762-1914-М.: Русский путь, 1995. - С. 539.

${ }^{31}$ Лучин В.О. Конституция Российской Федерации: Проблемы реализации. - М.: ЮНИТИ-ДАНА, 2002. - С. 407-408.
}

жизнью, реально действующими в обществе социально-экономическими и политическими институтами на фоне игнорирования «буквыl» и «духа» Конституции основными политическими силами в обществе. Отчего это происходит? Почему одни конституции успешно работают и реально воплощаются в жизнь, а другие оказываются мало совместимыми с ней?

Официально принято считать, что Конституция России - добротный конституционный документ, не уступающий своим зарубежным аналогам. При этом в федеральном центре часто подчеркивается, что ресурс Конституции еще не выработан, в связи с чем вопросы о ее замене ставить преждевременно. То есть в ситуации расхождения конституционных установлений с реальностью выбор «высокими» политиками и чиновниками делается в пользу якобы правильности Конституции - просто реальные политические и социально-экономические процессы в стране не соответствуют Основному закону (!). Такая позиция, прямо скажем, вызывает недоумение. Конституция в целом должна соответствовать реальным общественным отношениям, иначе ее функциональность как главного закона, регулирующего жизнь общества и государства, будет неуклонно стремиться к нулю.

Но какими должны быть взаимоотношения Конституции и действительности? Насколько допустимо расхождение между ними?

Современная конституционно-правовая наука, к сожалению, не дает четкого ответа на эти вопросы.

Правовые конструкции часто рассматриваются практически в отрыве от реальных общественных процессов. Как представляется, это обусловлено в значительной мере тем, насколько Конституция выполняет возложенные на нее функции.

Традиционно выделяются несколько функций конституции: учредительная, организаторская, внешнеполитическая, идеологическая и юридическая. Нас интересуют те из них, что непосредственно связаны с процессами управления обществом и государством, а именно - учредительная и организаторская.

Учредительная функция конституции проявляется в том, что «конституция, появляясь в результате коренных изменений в жизни общества, становится политико-правовой основой его развития на следующем историческом этапе... "Учредительная" в данном случае означает: Конституция либо закрепляет то, что уже существует как результат общественных отношений, либо создает предпосылки для совсем новых общественных отношений, уже созревших в обществе, но еще не могущих возникнуть до тех пор, пока не 
DOI: $10.7256 / 1811-9018.2013 .12 .10142$

При цитировании этой статьи сноска на dоі обязательна

\section{Право и политика $12(167) \cdot 2013$}

будет необходимой для них правовой базы, которая и учреждается с принятием Конституции» ${ }^{32}$.

Организаторская функция конституции заключается в том, что она «не только оформляет достигнутое и ставит новые задачи перед обществом и государством, но и стимулирует политическую активность, нацеливает государственные органы и общественные объединения, всех граждан на деятельность в духе нового основного закона. Конституция должна не только отражать роль соответствующих факторов, но и содержать определенные механизмы их достижения» ${ }^{33}$.

Итак, Конституция должна, в первую очередь, ставить перед обществом и государством некие цели и задачи. Это - главная функция любой конституции как инструмента управления обществом и государством; прочие функции конституции носят факультативный характер.

Целесообразность - едва ли не главное свойство любой созданной человеком системы. В таких искусственных системах, как государство, подчиненность их состава и структуры поставленной цели настолько очевидна, что ее следует признать фундаментальным системным свойством.

Цель, ради которой создается государство, предопределяет всю его архитектонику. Государство есть средство достижения цели, а не наоборот. Если поставленная цель не может быть достигнута за счет имеющихся возможностей, государство демонтируется и на его месте создается новое. Разумеется, не всякая цель достижима, поэтому очень важно установить реализуемость цели еще до начала построения государственной системы ${ }^{34}$.

Очевидно, что цель существования любой государственной системы должна быть отражена в конституции страны. Однако в Конституции Российской Федерации раздел, посвященный целеполаганию государственной системы, отсутствует. Думается, это не случайно: разработчики Конституции либо не имели четко оформленных целей, либо по тем или иным причинам обошли вопрос целеполагания стороной.

В то же время несколько целевых установок отечественного конституционализма все-таки нашли отражение в Преамбуле Конституции. Среди них:

первая: утверждение прав и свобод человека, гражданского мира и согласия;

\footnotetext{
${ }^{32}$ Конституционное право: Энцикл. словарь / Под ред. С.А. Авакьяна. - М., 2000. - С. 313-314.

${ }^{33}$ Там же.

${ }^{34}$ Тарасенко Ф.П. Прикладной системный анализ. - М.: КНОРУС, 2010. - C. 52.
}

вторая: сохранение исторически сложившегося государственного единства;

третья: признание общепризнанных принципов равноправия и самоопределения народов;

четвертая: возрождение суверенной государственности России;

пятая: утверждение незыблемости демократической основы России;

шестая: благополучие и процветание России.

На первый взгляд, цели развития страны Конституцией предусмотрены, причем касаются они не только личности, но и народа как совокупности отдельных личностей, и государства. Однако, нам представляется, перечисленные цели российской государственной системы сформулированы в Преамбуле Конституции таким образом, что впору усомниться: нужно ли достигать этих целей и достижимы ли они в принципе?

Первое. Вряд ли кто-то сегодня сомневается в том, что одной из ключевых целей или даже ценностей конституционализма должна стать личность, ее права, интересы и в иелом самочувствие. В то же время каждый может задать справедливый вопрос: каким образом данная конструкция реализуется через механизм «общепринятых» прав и свобод человека? Где и кем перечень этих общепринятых прав и свобод предусмотрен? Международные конвенции? Их подписывают далеко не все государства, и не все исполняют подписанное, да и сами конвенции содержат совершенно различные перечни прав и свобод. Относится ли к ним право на жизнь, если во многих странах, в том числе в таких, демократичность которых никем вроде бы не оспаривается (например, в США), применяется смертная казнь? Открытым остается вопрос о том, можно ли нарушать права и свободы одних людей ради того, чтобы обеспечить те же права для других? Что касается гражданского мира и согласия, то это также довольно спорные категории. Является ли согласие с кем-либо конкретным либо даже со всеми целью? Нужно ли соглашаться с теми, кто, например, поддерживает терроризм, разжигает рознь и тому подобное? Не только не нужно, но напротив - категорически противопоказано. На наш взгляд, иели государственной системы в данном случае сформулированы крайне неудачно.

Второе. Сохранение исторически сложившегося государственного единства, на первый взгляд, представляется крайне важным, особенно учитывая политический контекст эпохи принятия действующей Конституции, характеризовавшийся «парадом суверенитетов». Однако только ли государственное единство необходимо сохранять? Ведь государство должно соот- 
DOI: $10.7256 / 1811-9018.2013 .12 .10142$

При цитировании этой статьи сноска на dоі обязательна

Правовая и политическая мысль

ветствовать и другим системным представлениям - в частности, оно должно еще и развиваться. Отстающее в своем развитии государство рано или поздно теряет системное свойство единства, как бы оно ни защищало его военными и политическими методами. Мы полагаем, что данная цель конституционализма сформулирована как минимум некорректно.

Tретье. Признание общелризнанных принциипов равноправия и самоопределения народов - это не цель, нам представляется, а антицель государственной сиcmемы. Буквальная реализация такой «цели» означает расчленение государства. Да и само по себе право народов на самоопределение не является столь уж общепризнанным, особенно на фоне отсутствия единства международно-правовых подходов к данному вопросу. Наряду с очевидным и необходимым принципом государственного суверенитета международное право знает и самоопределение наций, и институт признания государств (правительств), которому придают порой слишком большое значение, утверждая, что источник суверенитета государства заключается в его признании международным сообществом ${ }^{35}$. Это признание, как правило, выливается в одобрение курса так называемых «борющзихся нациий», представленных некими организациями, присвоившими себе властные полномочия (признание «восставщей и воюющей стороныл»). Данная конструкция еще оправдывала себя на этапе борьбы с колониализмом, но на сегодняшний день признание прав «борющихся нациий», а следовательно, и права наций на самоопределение становится «гипотетическим и ложным» ${ }^{36}$. После признания рядом стран в 2008 г. Косово в качестве суверенного государства хрупкая международно-правовая конструкция государственного суверенитета была окончательно разрушена. СССР формально признавал самоопределение народов и право союзных республик на выход из состава Союза, что и стало одним из факторов его быстрого распада. Мы уверены, что на роль изели государственной системы принцип самоопределения народов категорически не подходит.

Четвертое. Возрождение суверенной государственности России - это политический лозунг, возник-

\footnotetext{
${ }^{35}$ Т.н. конститутивная теория международного признания Л. Оппенгейма, Г. Лаутенпаха и др.

${ }^{36}$ Sibert M. Traite de droit international public. - T. I. - P., 1951. - Рp. 304-305. Аналогичная правовая позиция содержится в решении Верховного Суда Канады 1998 г. по проблеме Квебека, подтвердившего наличие права сецессии только у т.н. «угнетенных народов», но при этом отрицающего данное право как таковое.
}

ший на фоне необходимости решения текущих задач российской политической элиты и власти начала 1990-х годов. Сегодня данный лозунг неактуален. Тем более что суверенность - свойство любой государственной системы; в ее отсутствие вообще неправомерно вести речь о таких институтах, как Конституция, государственность и прочее. Россия сегодня в полной мере обладает суверенной государственностью.

Пятое. Утверждение незыблемости демократической основы России также вряд ли уместно рассматривать в качестве цели, поскольку понятие «демократия» в настоящее время крайне неоднозначно. «Демократия, - справедливо отмечает А.Д. Керимов, - вопреки обыденному представлению, не есть власть народа или власть большинства... Демократия - это определенная технология обретения и осуществления государственной власти меньшинством с помощью большинства, с опорой на большинство, но далеко не в интересах и во благо большинства». Далее автор продолжает свою мысль: «Миром правит меньшинство; и это касается всех сфер общественной жизнедеятельности, в том числе и тех, где есть иллюзия властвования большинства... В любом человеческом сообществе, вне зависимости от его численности, внутренней структуры, принципов деятельности и преследуемых целей... с неизбежностью происходит узурпация власти» ${ }^{37}$. Демократия - это далеко не пресловутая «власть народа», она «отнюдь не гарантирует того, что бразды правления непременно попадут в руки наиболее достойных представителей нацииџ. Принятие решений демократическим способом, то есть на основании воли большинства или даже единогласного волеизъявления всех, не обеспечивает автоматически их правильности и справедливости.

Порок демократии усматривается также в том, что «она создает и у широких масс населения, и у правящей элиты ложное представление, согласно которому в отправлении властных полномочий в государственноорганизованном социуме могут участвовать буквально все и каждый».

Нельзя не согласиться и с тем, что «в определенной части демократическая идеология обнаруживает свою крайнюю лицемерность», что она «одержима неуемным стремлением навязать по любому поводу и всем без исключения весьма произвольно трактуемую волю больиинства (точнее волю тех, кто выступает от имени большинства)». На этом фоне «победное

\footnotetext{
${ }^{37}$ Керимов А.Д. Современное государство: вопросы теории. - М.: Норма, 2007. - С. 25-26, 28-29.
} 
DOI: $10.7256 / 1811-9018.2013 .12 .10142$

При цитировании этой статьи сноска на dоі обязательна

\section{Право и политика $12(167) \cdot 2013$}

шествие демократии по миру» приобретает несколько иные смысловые коннотации, нежели те, к которым традиционно апеллирует Конституция России. «B результате демократия как политическое мировоззрение и как технология успешно осуществляет экспансию там, где это не представляется необходимым ни с позиичй здравого смысла, ни с точки зрения достижения общего блага» ${ }^{38}$. Это ли не иллюстрация сегодняшних глобальных процессов?

Мы убеждены, что понятие «демократия» в современный период слишком неконкретно, но, к сожалению, оно абсолютизировано и идеализировано. Демократия как таковая не гарантирует ни справедливого, ни эффективного правления. Демократия создает у масс иллюзию сопричастности к принятию решений, иллюзию того, что ключевые государственные решения принимаются едва ли не каждым человеком вне зависимости от его компетенции. Наконец, игнорирование некоторыми «демократиями» государственных границ - это одна из ключевых проблем современности. Как заметил еще в XIX веке отечественный мыслитель К. Победоносцев, «при демократическом образе правления правителями становятся ловкие подбиратели голосов, со свочми сторонниками, механики, ловко орудуюшие закулисными пружинами, которые приводят в движение кукол на арене демократических выборов» ${ }^{39}$. На наш взгляд, ставить такого рода цели во главу угла развития государства не следует.

«Проблема суверенитета и демократии, - как справедливо полагает С.А Авакьян, - в их переплетении не может не быть политической... Причина, вероятно, кроется в том, что начинается незамедлительный поиск общественных сил, которые “единственно” есть защитники как суверенитета, так и демократии, способные соединить эти понятия в построении демократического общества и управлении государством» ${ }^{40}$.

Шестое. Благополучие и процветание России - прекрасные лозунги, не более того, к тому же неконкретные и практически не обеспеченные механизмами реализации. Именно лозунги, идеалы - к которым мы должны стремиться, но которых (и мы должны это осознавать) практически нельзя достигнуть. Полагаем, что присутствие такого рода целейидеалов вполне допустимо, однако только наряду с целями, объективно реализуемыми.

\footnotetext{
38 Там же. - С. 36, 39, 40, 43.

${ }^{39}$ Цит. по: Русский дом. - 2002. - № 3.

${ }^{40}$ Авакьян C.A. Точка отсчета - народ // Российская газета. - 2006. -28 окт.
}

\section{О неотложности конституционной реформы}

«Прежде всего давайте внесем ясность по поводу того, как следует воспринимать идеи конституционного реформирования, поскольку от этого немало зависит их поддержка или отторжение. Еще со времен марксизма и тем более ленинизма прочно включена в сознание людей так называемая классовая идея конституционализма; ее суть в том, что Конституции знаменуют смену общественной формации, существенные перемены в формах собственности, переход власти в руки нового класса, изменение общественного строя. Те, кто сегодня правит нашим государством, не составляют исключения - они учились по учебникам, напичканным марксистско-ленинскими догматами, и, как бы ни перестраивались, все равно заученное крепко сидит в памяти.

Причем, как это ни парадоксально, прежние идеи, несколько освобожденные от классового налета, в целом остались пригодными правящей элите и сегодня. Для чего - понятно: для консервативного сохранения неприкосновенности действующей Конституции России под флагом того, что разработка конституционных реформ не нужна в условиях только-только успокоившегося общества. Она, мол, даст лишь неуверенность людям: многообразие форм собственности есть, политический плюрализм провозглашен, права и свободы записаны - чего же еще хотеть <...>

Если этого не делается, то фактически все равно происходит коррекция конституционных норм, но уже текущим законодательством и решениями конституционных судов. У некоторых исследователей как прошлого, так и наших дней эти метаморфозы получили название “преобразования Конституции”. Все бы ничего, но как-то не учитывается, что в этом случае имеет место размывание конституционной основы нашей жизни; Конституцию принимал народ, а приноравливает ее теперь к условиям жизни узкий круг законодателей и конституционных судей, и кто же сказал, что у них есть на это абсолютное, ничем не ограниченное право?» ${ }^{41}$

Нами установлено, что из шести целей России как сложного системного образования, сформулированных в Преамбуле Конституции Российской Федерации, одна - категорически неприемлема, две - собственно целями не являются, одна - крайне неудачно сформулирована, ещзе одна - спорна и последняя - неполна. То есть с

\footnotetext{
41 Авакьян C.A. Десять причин для конституционных реформ в России // Независимая газета. - 2012. - 16 окт.
} 
DOI: $10.7256 / 1811-9018.2013 .12 .10142$

При цитировании этой статьи сноска на dоі обязательна

Правовая и политическая мысль

нормативно урегулированными целями и задачами имеются довольно сушественные проблемы.

О чем говорят нам объективно существующие задачи действующей Конститущии России? Среди них обычно выделяются: оформление отказа России от советской формы власти, утверждение нового конституционного строя, демократизма государства и общества, политического плюрализма, основных прав и свобод человека и гражданина, институтов государственной власти и основ местного самоуправления, федеративного устройства государства, плюрализма форм собственности и свободы предпринимательской деятельности ${ }^{42}$. Однако все это также не прибавляет ясности в вопросе о конституционном целеполагании. Вряд ли постановка задачи «отказа от советской формы власти» может существенным образом удовлетворить потребность в целеполагании российского общества и государства на перспективу.

Таким образом, целесообразность в системе российского конституционализма является «слабым звеном»: из Конституции совершенно неясно, зачем страна существует и куда она движется (должна двигаться) в своем развитии. А между тем туманность целей государственной системы рано или поздно приводит к проблемам в ее функционировании, поскольку аппарат управления такой системой занят, в основном, реакцией на текущие изменения среды и не в состоянии действовать стратегически. Отсюда и многие проблемы отечественной государственности, ставшие уже хроническими. Как справедливо отмечено Н.А. Бобровой, конституционное обеспечение реформирования государства происходит «в условиях переходности общества и экономики из исходного дореформенного состояния в другое (нечетко определенное) состояние, являющееся целью реформирования», обостряется «противоречие между динамично изменяющимися условиями развития институтов гражданского общества и экономики, с одной стороны, и неподвижными границами конституционного регулирования важнейших понятий и принципов, которые должны лежать в основе обновляющегося законодательства Российской Федерации, - с другой» ${ }^{43}$.

Уиравление, как известно, - это цуеленаправленное воздействие на систему, которой в нашем случае является и государство, и общество. Управление системой включает в себя в качестве обязательного компонента

\footnotetext{
${ }^{42}$ Конституционное право: Энцикл. словарь / Под ред. С.А. Авакьяна. - М., 2000. - С. 315-316.

${ }^{43}$ Боброва Н.А. Конституционный строй и конституционализм в России. - М.: ЮНИТИ-ДАНА, Закон и право, 2003. - С. 15.
}

цель управления, куда входит не только конечное желаемое состояние системы, но и вся траектория движения к нему с учетом первичности публично задаваемых ценностей и целей развития перед цуелями административно-управленческими ${ }^{44}$. Однако выявление системных целей российского общества и государства представляет определенные сложности. Выразителем интересов любой организации, органа или государства в целом является его руководство; оно формулирует цели органа в условиях наличия конфликта интересов данного органа с окружающей средой, а также со своими личными интересами. В результате провозглашаемые тем или иным органом либо государством цели не всегда совпадают с истинными. Закрепленные на конституционно-правовом уровне цели в процессе их практической реализации существенным образом видоизменяются, подчас трансформируются в свою противоположность.

Как пишет Р. Акофф, «многие руководители компаний утверждают, что их главная цель - максимизация прибыли. Однако беспристрастная проверка их поведения обнаруживает, что эта цель не является у них доминирующей. В противном случае директора работали бы в менее роскошных кабинетах, летали бы на рейсовых самолетах, останавливались бы в средних отелях и так далее. Ясно, что большинство менеджеров склонны пожертвовать по крайней мере частью прибыли во имя обеспечения себе приемлемого качества... жизни... Стремление менеджмента обеспечить себе высокое качество жизни не является тайной для многих людей, ничего не выигрывающих от этого стремления, и они негодуют по этому поводу... Иногда менеджеры испытывают в подобных случаях чувство вины. Чем сильнее такое чувство, тем глубже они уходят в оборону; следовательно, тем более сопротивляются изменению. Это также мешает развитию» ${ }^{45}$.

В данном случае на примере работы коммерческих компаний показано, каким образом происходит подмена целей в крупных организационных структурах. Промежуточная административно-управленческая задача - обеспечение условий работы руководства компании, - которая является средством для достижения цели более высокого уровня (развитие компании), в реальности ставится на первое место, что, в конечном счете, препятствует достижению целей высшего уровня.

Обеспечение сохранения и развития страны путем

\footnotetext{
${ }^{44}$ Тарасенко Ф.П. Прикладной системный анализ. - М.: КНОРУС, 2010. - C. 134-137.

${ }^{45}$ Цит. по: Тарасенко Ф.П. Указ. соч. - С. 134-137.
} 
DOI: $10.7256 / 1811-9018.2013 .12 .10142$

При цитировании этой статьи сноска на dоі обязательна

\section{Право и политика 12 (167) • 2013}

защиты ее территориальной целостности, экономической и национальной безопасности подменяется созданием колоссального госаппарата, поглощенного решением внутренних проблем, а обеспечение сохранения народонаселения путем достижения достойного уровня и качества жизни граждан на всей территории страны трансформируется в создание все новых проблем для этих граждан.

Нет ничего удивительного в том, что на фоне такого конституционного целеполагания нормы Основного закона воспринимаются как нечто, оторванное от реальности. Между тем цели и задачи аппарата управления государством, закрепленные в Конституции, должны быть:

во-первых, реалистичны, достижимы при наличных финансовых, материальных и временных ресурсах;

во-вторых, конкретны, чтобы любое продвижение к цели вносило вклад в решение именно данной проблемы, а не какой-то другой;

в-третьих, измеримы, что позволит отслеживать процесс движения к цели путем измерений ${ }^{46}$.

«Провисание» хотя бы одного из указанных факторов делает конституционное целеполагание дефектным, что отражается на перспективах всего конституционного строя. Поэтому довольно распространенные предложения по поиску эволюционных путей выхода из кризиса конституционализма, такие как «правовое оформление института конституциионной ответственности министров» или «расширение средств и методов парламентского контроля за деятельностью исполнительной власти» ${ }^{47}$, хотя в целом могут быть поддержаны, при существующей системе конституционного целеполагания, на наш взгляд, не принесут желаемых результатов. Начинать процесс управления развитием государства следует с четкой формулировки изелей и иенностей этого государства как системного образования. Желательно последующее закрепление так называемого дерева целей в конституционном тексте, причем не в тезисной форме и не в Преамбуле Конституции, для этого мало подходящей.

При формулировании целей государственной системы в Конституции необходимо также учитывать значительное число субъектов конституционных правоотношений, а также оценку ими сложившейся ситуации с совершенно разных позиций. Множественность

${ }^{46}$ Тарасенко Ф.П. Указ. соч. - С. 134-137.

${ }^{47}$ Кравец И.А. Конституционализм и российская государственность в начале XX века: Учеб. пособие. - М.: ИВЦ «Маркетинг»; Новосибирск: ООО «Издательство ЮКЭА», 2000. - С. 345-346. интересов субъектов общественных отношений - это аксиома. Любое изменение Конституции может вызвать как их поддержку, так и неодобрение.

Наукой и практикой выработано три основных принципа урегулирования интересов множества субъектов.

Первый. Принциип «приоритета меньшинства» приводит к осуществлению вмешательства, выгодного какому-либо одному субъекту, в то время как интересы других не принимаются во внимание. В качестве примеров реализации данного принципа можно привести различные формы диктатуры, автократии, иерархической организации. «В царской России, - пишет С.А. Авакьян,- идеологизмом... была триада: самодержавие, православие, народность. Вроде бы уже тогда уповали на народ? Нет, на деле народом считалось население страны, да и то как совокупность подданных императора. Власти народа как его права участвовать в решении государственных дел, тем более решать их, не было» ${ }^{48}$. При некоторых обстоятельствах (таких как война, разного рода чрезвычайные ситуации) подобная идеология может стать оптимальной. Однако с ее реализацией связан ряд особенностей, которые неизбежно придется учитывать. Осуществление такого подхода к решению проблем «меньшинства» обязательно вызовет недовольство остальных участников ситуации, поэтому у принявших эту идеологему должна быть сила, достаточная для подавления недовольных.

Второй. Согласно принципу «приоритета группь»» среди участников ситуации имеется некоторое количество субъектов, одинаково важных. Поэтому вмешательство должно проводиться с учетом их интересов. Это, с одной стороны, осложняет его проектирование, но с другой - открывает возможность использования ресурсов всех субъектов. Известно множество примеров реализации названного принципа (национализм, коммунизм, любая групповая деятельность, в том числе партийная, религиозная и тому подобное). В качестве негативной стороны данной идеологемы можно отметить, что зачастую она агрессивна, ведет к наращиванию силовых структур. Также она заключает в себе противоречие между провозглашаемым равенством внутри группы и необходимостью организации групповой деятельности, то есть созданием иерархических структур.

Вот как об этом пишет С.А. Авакьян: «В советское время возвысили принцип классового расслоения.

\footnotetext{
${ }^{48}$ Авакьян С.А. Точка отсчета - народ // Российская газета. - 2006. -28 окт.
} 
DOI: $10.7256 / 1811-9018.2013 .12 .10142$

При цитировании этой статьи сноска на dоі обязательна

Правовая и политическая мысль

Официально объявляли о принадлежности власти то рабочим, то рабочим и крестьянам, то трудовому народу, то трудящимся. Формально говорили о народе. Но конституционно власть закреплялась все-таки не за народом, а за государственными органами. Конституция РСФСР 1918 года начиналась “Декларацией прав трудящегося и эксплуатируемого народа”. В ее первой статье Россия объявлялась республикой Советов рабочих, солдатских и крестьянских депутатов. "Вся власть в центре и на местах принадлежит этим Советам". По Конституции 1936 года СССР провозглашался социалистическим государством рабочих и крестьян, в котором вся власть принадлежала трудящимся города и деревни в лице Советов депутатов трудящихся. В разрабатывавшейся более 15 лет и принятой в 1977 году Конституции СССР как Основном Законе развитого социализма записали, что “вся власть в СССР принадлежит народу” (статья 2)... Но характерно: даже сказав о принадлежности власти народу, творцы Конституции все равно записали, что “народ осуществляет государственную власть через Советы народных депутатов, составляющие политическую основу СССР”» ${ }^{49}$.

Tpemuй. Наиболее продуктивной идеологией следует считать принщип «приоритета каждого». В основе его лежат два постулата: «нет ни одного одинакового субъекта» и «несмотря на различия, все субъекты равноценны и равноправны». Отсюда следует, что неправильно решать проблемы одних за счет других. Правильным признается только улучшающее вмешательство - такое изменение проблемной ситуации, которое положительно оценивается хотя бы одним из ее участников и неотрицательно - всеми остальными. Решение одних проблем не должно приводить к созданию новых. Наиболее серьезной проблемой реализации улучшающих вмешательств является противоречивость интересов участников проблемной ситуации, порой доходящая до конфликтности ${ }^{50}$.

Отечественный опыт урегулирования интересов разных субъектов конституционно-правовых отношений разнообразен. Страна знала и принцип «приоритета меньшинства» (дореволюционный период), и принцип «приоритета группьl» (советский период).

В государственном строительстве в период с 90-х годов прошлого века сложилась довольно неоднозначная ситуация:

во-первыx, формально, на уровне конституционно-правового регулирования и разного рода полити-

\footnotetext{
${ }^{49}$ Авакьян С.A. Точка отсчета - народ // Российская газета. - 2006. -28 окт.

${ }^{50}$ Тарасенко Ф.П. Указ. соч. - С. 15-18.
}

ческих деклараций провозглашается принцип «приоритета каждого» (он читается в конституционных нормах о правах и свободах человека и гражданина, провозглашении социального характера государства и тому подобном);

во-вторых, реальная система власти «заточена» под принцип «приоритета группы» (это проявляется в действующей избирательной и партийно-политической системах, способе формирования органов власти разных уровней); это «власть бюрократии, которой совсем не хочется всерьез воспринимать право народа на власть, а видеть в нем демократическую ширму для своего реального полновластия $\rangle^{51}$;

в-третьих, по результатам развития страны нами делается вывод, что реализуется принцип «приоритета меньшинства» (в России показатель децильного коэффициента колеблется в пределах 14-15, притом что «критическим» для стабильности социальной системы признается уровень децильного коэффициента в два раза более низкий: 7-852).

Подобное свидетельствует, прежде всего, о том, что нормы Конституции декларативны и довольно существенно расходятся с реальной жизнью, а также о том, что действующая система власти пока не в силах не только реализовать поставленные перед ней цели и задачи, но даже сформулировать их. Преодоление кризиса конституционализма следует начинать с указания в конституционном тексте на конкретные цели и ценности.

Однако даже формулирование конституционных целей - задача нетривиальная, поскольку конечная цель существования российского общества и государства неизвестна, что влечет неопределенность в траектории движения к ней.

Науке известно два выхода из сложившейся ситуации. Первый состоит в том, чтобы дать субъективное определение конечной цели. Управление крупными социальными системами часто представляет собой

\footnotetext{
${ }^{51}$ Авакьян C.A. Точка отсчета - народ // Российская газета. - 2006. -28 окт.

52 Децильный коэффициент - отношение доходов самых богатых $10 \%$ населения к $10 \%$ самых бедных. По мнению С.Г. Кара-Мурзы, «если проводить сравнение корректно - после вычитания физиологического минимума, то в России фондовый децильный коэффициент будет равен не 15 , как утверждает правительство, и не 23 , как утверждают ученые РАН, и даже не 36 , как утверждают американские ученые - он будет измеряться тысячами... что является катастрофическим разрывом» // Цит. по: Коньков $H$. Россия - суперолигархия [Электронный ресурс] / Агентство политических новостей [сайт]. - URL: http://www.apn.ru/opinions/ article9378.htm (дата обращения 1.11.2013).
} 
DOI: $10.7256 / 1811-9018.2013 .12 .10142$

При цитировании этой статьи сноска на dоі обязательна

\section{Право и политика $12(167) \cdot 2013$}

именно такой метод. Однако при этом следует учитывать, что любая социальная идеология, утверждающая свое видение конечной цели, предлагает гипотезу, истинность которой является вопросом веры в нее. Очень часто такие гипотезы оказываются неверными, что рано или поздно приводит государственные и общественные системы к краху. Развитие при такой модели управления идет по типу маятника - система дрейфует из одного крайнего положения в другое практически без промежуточных состояний: «Или правит кучка богатеев и поставленных ими чиновников, а простой народ наливается злобой, или вчерашние бедняки приходят к власти и либо долго учатся ею пользоваться, причиняя при этом страдания своим же согражданам, либо быстро сами приобретают вкус к богатству» ${ }^{53}$.

Другой способ управления при невозможности выявить конечную цель - инкрементализм, внесение небольших, но улучшающих изменений, то есть последовательное определение наиболее предпочтительного направления следующего шага в пределах ближайшей траектории системы. Но, на наш взгляд, инкрементализм также не гарантирует успеха, поскольку даже в эволюционном развитии нередки тупиковые ветви. Первый шаг такого способа управления - это формулировка тезиса о том, что единственной универсальной ияелью существования системы является само ее существование ${ }^{54}$. То есть для России как сложной государственной системы целью является сохранение и дальнейшее развитие государства.

Традиционно выделяются следующие общие признаки и отличительные черты государства, характеризующие его как специфическую организацию общества: территория, население, публичная власть и суверенитет ${ }^{55}$.

Отсюда следует, что базовые ценности отечественной государственной системы, ее универсальные цели - это сохранение и развитие (приумножение, улучшение качества):

во-первых, территории - путем защиты территориальной целостности страны, ее суверенитета, защиты экономической и национальной безопасности страны;

во-вторых, населения-путем достижения достойного уровня и качества жизни граждан на всей территории страны, преодоления тенденций депопуляции.

${ }^{53}$ Авакьян C.A. Точка отсчета - народ // Российская газета. - 2006. -28 окт.

${ }^{54}$ Тарасенко Ф.П. Указ. соч. - С. 94-95

55 Энциклопедический словарь экономики и права [Электронный pecypc] / Академик [сайт]. - URL: http://dic.academic.ru/dic.nsf/ dic_economic_law/10016 (дата обращения 1.11.2013).

\section{Послесловие}

Мы убеждены, что четкая формулировка вышеизложенных ценностей в тексте Конституции, последующее законодательное развертывание более конкретных целей и задач государства в связи с указанными ценностями вернет отечественному конституционализму качество целесообразности.

Категории конституцчионализма и ичелесообразности неразделимы.

«Времена упадка, смуты, на грани распада и самого распада страны... неприязни и страха, испытываемого в мире к России, характерны именно для тех периодов, когда идея России исчезала, когда ни руководство не знало, куда идти, что в будущем, каковы ценности и смыслы, ни, соответственно, народ» ${ }^{56}$.

Крупный ученый-конституционалист С.А. Авакьян в своей известной статье обозначил десять основных причин для конституционных реформ в России:

первая: экономические и сочииальные факторы;

вторая: создание конституичионных основ гражданского общества;

третья: не просто провозглашение, но и гарантирование народовластия;

четвертая: прекращение господства исполнительной бюрократии;

пятая: устройство государства;

шестая: местное самоуправление;

седьмая: судебная власть;

восьмая: избирательная система;

девятая: дефекты существующего конституичионного регулирования;

десятая: необходимость оставить прошлое в прошлом ${ }^{57}$.

«...Если власть прислушается к конструктивным призывам, она имеет все шансы достойно завершить 20-летие, оставить в прошлом просчеты и ошибки, учесть разумные предложения и создать прочный (и спокойный!) фундамент будущего нашей страны. Есть достаточный срок для основательного конституционного реформирования» ${ }^{58}$.

Мы всецело разделяем позицию профессора С.А. Авакьяна. «Косметический ремонт» в государстве далее бесполезен - требуется «капитальная реконструкичия» и «живые» реформы.

\footnotetext{
${ }^{56}$ Национальная идея России. Программа действий (постановка задачи) / Под ред. С.С. Сулакшина. - М.: Научный эксперт, 2009. - C. 6.

${ }^{57}$ Авакьян С. А. Десять причин для конституционных реформ в России // Независимая газета. - 2012. - 16 окт.

${ }^{58}$ Там же.
} 
DOI: $10.7256 / 1811-9018.2013 .12 .10142$

При цитировании этой статьи сноска на dоі обязательна

Правовая и политическая мысль

\section{Библиография:}

1. Авакьян С.А. Десять причин для конституционных реформ в Рос-сии // Независимая газета. - 2012. 16 окт.;

2. Авакьян С.А. Конституция России: природа, эволюция, современ-ность. - М.: РЮИД, 1997;

3. Авакьян С.А. Конституция Российской Федерации: норма и действительность // Неприкосновенный запас. - 2008. - № 5 (61);

4. Авакьян С.А. Точка отсчета - народ // Российская газета. - 2006. -28 окт.;

5. Боброва Н.А. Конституционный строй и конституционализм в Рос-сии. - М.: ЮНИТИ-ДАНА, Закон и право, 2003;

6. Богданова Н.А. Категория «конституционализм» в науке конститу-ционного права // Российский конституционализм: проблемы и решения. - М., 1999;

7. Богданова Н.А. Система науки конституционного права. - М.: Юристъ, 2001;

8. Глигич-Золотарева М.В. Верификация дефиниций конституционной науки Vs. увлечение общими местами // Политика и общество. - 2009. - № 5;

9. Глигич-Золотарева М.В. Теория и практика федерализма: систем-ный подход. - Новосибирск: Наука, 2009;

10. Глигич-Золотарева М.В. Фрагментарный конституционализм // Труды Института государства и права РАН. - 2006. - № 3 (Конституционный строй России. Вып. 5). - М., 2006;

11. Егоров С.А. Конституционализм в США: политико-правовые ас-пекты. - М.: Наука, 1993;

12. Керимов А.Д. Современное государство: вопросы теории. - М.: Норма, 2007;

13. Коньков Н. Россия - суперолигархия [Электронный ресурс] / Агентство политических новостей [сайт]. - URL: http://www.apn.ru/opinions/article9378.htm (дата обращения 1.11.2013);

14. Кравец И.А. Конституционализм и российская государственность в начале XX века: Учеб. пособие. - М.: ИВЦ «Маркетинг»; Новосибирск: ООО «Издательство ЮКЭА», 2000;

15. Кравец И.А. Конституционализм: устойчивость власти и обще-ственного развития. - Новосибирск: Изд-е ИФиПр СО РАН, 1994;

16. Кравец И.А. Формирование российского конституционализма (проблемы теории и практики). - М.Новосибирск: ООО «Издательство ЮКЭА», 2002;

17. Леонтович В.В. История либерализма в России. 1762-1914. - М.: Русский путь, 1995;
18. Лучин В.О. Конституция Российской Федерации: Проблемы реализации. - М.: ЮНИТИ-ДАНА, 2002;

19. Медушевский А.Н. Конституционная монархия в Европе, Японии и России // Общественные науки и современность. - 1994. - № 6;

20. Медушевский А.Н. Что такое мнимый конституционализм? // Со-циологические исследования. - 1994. - № 2;

21. Рейснер М.А. Государство буржуазии и РСФСР. М.-Пг: Госиздат, 1923;

22. Степанов И.М. Грани российского конституционализма (XX век) // Конституционный строй России. Вып. 1. - М., 1992;

23. Степанов И.М. Уроки и парадоксы российского конституционализма. - М., 1996;

24. Тарасенко Ф.П. Прикладной системный анализ. М.: КНОРУС, 2010;

25. Топорнин Б.Н. Конституционная реформа - путь к правовому государству // Советское государство и право. - 1990. - № 4;

26. Чиркин В.Е. Конституционализм и современная цивилизация // Труды Института государства и права РАН. - 2006. - № 3 (Конституционный строй России. Вып. 5). - М., 2006;

27. Чиркин В.Е. Реформа российской Конституции: этапы и проблемы // Общественные науки и современность. 2000. - № 5;

28. Янов А. Монтескье против Маркса // Общественные науки и современность. - 1992. - № 1;

29. Sibert M. Traite de droit international public. T. I. - P., 1951.

\section{References (transliteration):}

1. Avak'yan S.A. Desyat' prichin dlya konstitutsionnykh reform v Ros-sii // Nezavisimaya gazeta. 2012. - 16 okt.;

2. Avak'yan S.A. Konstitutsiya Rossii: priroda, evolyutsiya, sovremen-nost'. - M.: RYuID, 1997;

3. Avak'yan S.A. Konstitutsiya Rossiiskoi Federatsii: norma i deistvitel'nost' // Neprikosnovennyi zapas. 2008. - № 5 (61);

4. Avak'yan S.A. Tochka otscheta - narod // Rossiiskaya gazeta. - 2006. -28 okt.;

5. Bobrova N.A. Konstitutsionnyi stroi i konstitutsionalizm v Ros-sii. - M.: YuNITI-DANA, Zakon i pravo, 2003;

6. Bogdanova N.A. Kategoriya «konstitutsionalizm» v nauke konstitu-tsionnogo prava // Rossiiskii konstitutsionalizm: problemy i resheniya. - M., 1999; 
DOI: 10.7256/1811-9018.2013.12.10142

При цитировании этой статьи сноска на dоі обязательна

\section{Право и политика 12 (167) • 2013}

7. Bogdanova N.A. Sistema nauki konstitutsionnogo prava. - M.: Yurist", 2001;

8. Gligich-Zolotareva M.V. Verifikatsiya definitsii konstitutsionnoi nauki vs. uvlechenie obshchimi mestami // Politika i obshchestvo. - 2009. - № 5;

9. Gligich-Zolotareva M.V. Teoriya i praktika federalizma: sistem-nyi podkhod. - Novosibirsk: Nauka, 2009;

10. Gligich-Zolotareva M.V. Fragmentarnyi konstitutsionalizm // Trudy Instituta gosudarstva i prava RAN. - 2006. -№ 3 (Konstitutsionnyi stroi Rossii. Vyp. 5). - M., 2006;

11. Egorov S.A. Konstitutsionalizm v SShA: politikopravovye as-pekty. - M.: Nauka, 1993;

12. Kerimov A.D. Sovremennoe gosudarstvo: voprosy teorii. - M.: Norma, 2007;

13. Kon'kov N. Rossiya - superoligarkhiya [Elektronnyi resurs] / Agentstvo politicheskikh novostei [sait]. URL: http://www.apn.ru/opinions/article9378.htm (data obrashcheniya 1.11.2013);

14. Kravets I.A. Konstitutsionalizm i rossiiskaya gosudarstvennost' $\mathrm{v}$ nachale KhKh veka: Ucheb. posobie. - M.: IVTs «Marketing»; Novosibirsk: OOO «Izdatel'stvo YuKEA», 2000;

15. Kravets I.A. Konstitutsionalizm: ustoichivost' vlasti i obshche-stvennogo razvitiya. - Novosibirsk: Izd-e IFiPr SO RAN, 1994;

16. Kravets I.A. Formirovanie rossiiskogo konstitutsionalizma (problemy teorii i praktiki). - M.-Novosibirsk: OOO «Izdatel'stvo YuKEA», 2002;

17. Leontovich V.V. Istoriya liberalizma v Rossii. 1762 1914. - M.: Russkii put', 1995;
18. Luchin V.O. Konstitutsiya Rossiiskoi Federatsii: Problemy realizatsii. - M.: YuNITI-DANA, 2002;

19. Medushevskii A.N. Konstitutsionnaya monarkhiya v Evrope, Yaponii i Rossii // Obshchestvennye nauki i sovremennost'. - 1994. - № 6;

20. Medushevskii A.N. Chto takoe mnimyi konstitutsionalizm? // So-tsiologicheskie issledovaniya. - 1994. - № 2;

21. Reisner M.A. Gosudarstvo burzhuazii i RSFSR. - M.Pg: Gosizdat, 1923;

22. Stepanov I.M. Grani rossiiskogo konstitutsionalizma (KhKh vek) // Konstitutsionnyi stroi Rossii. Vyp. 1. - M., 1992;

23. Stepanov I.M. Uroki i paradoksy rossiiskogo konstitutsionalizma. - M., 1996;

24. Tarasenko F.P. Prikladnoi sistemnyi analiz. - M.: KNORUS, 2010;

25. Topornin B.N. Konstitutsionnaya reforma - put' $\mathrm{k}$ pravovomu gosudarstvu // Sovetskoe gosudarstvo i pravo. - 1990. - № 4;

26. Chirkin V.E. Konstitutsionalizm i sovremennaya tsivilizatsiya // Trudy Instituta gosudarstva i prava RAN. - 2006. - № 3 (Konstitutsionnyi stroi Rossii. Vyp. 5). - M., 2006;

27. Chirkin V.E. Reforma rossiiskoi Konstitutsii: etapy i problemy // Obshchestvennye nauki i sovremennost'. 2000. - № 5;

28. Yanov A. Montesk'e protiv Marksa // Obshchestvennye nauki i sovremennost'. - 1992. - № 1;

29. Sibert M. Traite de droit international public. T. I. - P., 1951. 